\title{
*Why a special look at women?
}

\author{
Truida Prekel \\ School of Business Leadership, University of South Africa, Pretoria
}

\author{
"Expansion of lecture at SBL seminar: 'Women - a vital human \\ resource', Johannesburg, October 25-26, 1979.
}

\begin{abstract}
Women in employment in South Africa are viewed from four perspectives: The South African economy and its need for capable and skilled people; the employer and existing needs, practices and policies; the social environment at work and at home and typical traditions, misunderstandings, stereotypes and conflicts; and problems generally experienced by working women. Some statistics indicate trends regarding employment of women, also in management positions; the attention of employers is focused on many forms of unconscious, even well-meant discrimination; the role of culture in determining male and female attitudes regarding the roles of women, and the recent polarization of men and women due to extremism and lack of understanding, are discussed. The problems experienced by working women are mostly culture-based, but some are vested in the women themselves, and others in the environment. All these aspects must be understood by women and by employers if the vast potential of women is to be utiliz. ed in South Africa.
\end{abstract}

S. Afr. Bus. Mgmt 1980, 11: $62-68$

Vroue in die arbeidsmag in Suid-Afrika word vanuit vier oogpunte beskou: Die Suid-Afrikaanse ekonomie en die behoefte aan bekwame, geskoolde mense; die werkgewer en bestaande behoeftes, praktyk en beleid; die sosiale omgewing by die werk en tuis en tipiese tradisies, wanbegrippe, stereotiepe en konflikte; en probleme wat algemeen deur werkende vroue ondervind word. Sekere statistieke dui neigings in indiensneming van vroue aan, ook in bestuursposte; werkgewers se aandag word gevestig op baie vorms van onbewuste, selfs goed-bedoelde diskriminasie; die rol van kultuur in die bepaling van mans en vroue se houdings oor die rolle van vroue word bespreek, asook die onlangse polarisering van mans en vroue weens ekstremisme en gebrek aan begrip. Die probleme wat werkende vroue ondervind, berus meestal op kultuur, maar sommige le in die vroue self, terwyl ander in die omgewing voorkom. Al hierdie aspekte moet deur vroue en deur werkgewers begryp word as die waardevolle potensiaal van vroue in die Suid-Afrikaanse ekonomie benut moet word.

S.-Afr. Tydskr. Bodryfsl. 1980, 11: 62-68
In the past decade feminists have worked so hard at proving that women are 'equal' to men, that men and women alike may ask 'Why pay special attention to women in a discussion like this?' One could appear to be a sell-out or a defeatist from the Woman's Lib point of view. But the increasing interest of so many people, both men and women, in this topic, is a clear indication of the need for a special look at working women in South Africa.

Working women will be viewed from four perspectives:

- The South African economy, and its need for capable and skilled people.

- The employer, and existing needs, practices and policies.

- The social environment at work and at home, and typical traditions, misunderstandings, stereotypes and conflicts.

- Problems typically experienced by working women, some of them stemming from the environment, and some vested in women themselves.

The objective of this 'special look' is that an understanding of the situation of the working woman, and particularly of the career-oriented woman, will set the stage for further discussion and consideration of the issues involved among all individuals concerned, and will assist employers and women alike to make the best of the new opportunities and possibilities which are increasingly opening up to women.

Although there has been a rapid increase in the use of women world-wide,' and in South Africa, both in terms of numbers, and of positions of responsibility, it is still evident that even many 'enlightened' employers continue to use most of their women employees well below their real potential. ${ }^{2}$

\section{The South African economy and its human resources needs}

One of the major concerns in South Africa today is the real economic and political danger of our increasing rate of unemployment - and people promoting the better utilization of women have been challenged: 'How can you advocate increased use of women against the reality that they are keeping Black, Coloured or Asian heads of families out of a job?' A closer examination of relevant statistics shows that this is not the case; ${ }^{3,4}$ that although White women are also a 'minority group' (in the American sense of the word), there is usually such a dif- 
Table 1 Labour force participation rates of women in South Africa

\begin{tabular}{lcccc}
\hline & Married & Divorced & Widowed & All women \\
\hline 1951 & $11,3 \%$ & & & \\
1960 & $19,4 \%$ & $67,9 \%$ & $20,4 \%$ & $29,2 \%$ \\
1970 & $27,9 \%$ & $71,3 \%$ & $23,5 \%$ & $35,5 \%$ \\
1980 & & & & $40 \%$ \\
Estimate & $35 \%$ & $78 \%$ & $26 \%$ & $42 \%$ \\
1981 & & & & $42 \%$ \\
Forecast & & & & 40.040 \\
\hline
\end{tabular}

Sources: SA Department of Statistics and Human Sciences Research Council.

ference between the educational and socio-economic level of the women that we have in mind, and that of most of the people of the other races, that there is little if any competition for the same jobs between these groups. In fact, ironically, the economy is at present hampered by a shortage of skilled and managerial workers and this shortage could retard growth and thus aggravate unemployment. Thus better utilization of women could actually help to provide the administrative and managerial superstructure essential for the creation of more jobs in the economy as a whole. (This point is discussed in more detail in another article by the author ${ }^{5, p n 36-40}$ and in various publications on research done at the Human Sciences Research Council on manpower supply and demand forecasts).

The statistics bear this out: There has been a rapid increase in the employment rate of women in South Africa over the past 30 years, and particularly in the past decade, as shown in Table 1. (Unless otherwise specified, statistics refer to White women, since this article is mainly concerned with improved utilization of the abilities of the large group of well-educated, mature, middle-class women, most of whom are White.)

There has furthermore been a dramatic increase in the numbers of White women holding managerial positions. According to statistics of the Department of Labour ${ }^{6}$ numbers almost trebled from 5277 in 1969 to 15535 in 1977 , and more than quadrupled to 21606 in 1979. Table 2 shows the numbers of men and women employed in management over the years 1969-1979.
Over the same period the numbers of White men, and of men and women of the other races, have also increased, which indicates that the real need for human resources creates opportunities for capable people regardless of sex and colour, and that one group need not feel threatened by another, providing the individuals are career-orientated and have, or obtain, the necessary training and experience.

The military situation in South Africa is another reason why women are being used increasingly, not only in the Defence Force, in a wide variety of positions and holding ranks up to colonel and brigadier, but also in the public and private sectors where women are filling the gaps caused by the withdrawal of thousands of men from the open labour market.

In order to make the best possible use of available people, the Defence Force has been highly enterprising as an employer of women, and is actively recruiting women for a large number of non-combatant positions. The Defence Force is one of the few employers in South Africa which has carefully reviewed all positions which had previously been 'men's only', to establish whether they could really not be held by a woman. Over 4600 such positions were identified, and large numbers of women have been, and are still being, recruited and trained to take up these new job opportunities. Women, as a percentage of the total Permanent Force have increased from $0,6 \%$ in 1973 to $7,3 \%$ in 1979 . 5 p $40-42$

Against this background, the call for better utilization of women is not only in the interest of women, or even of employers; it is in the interests of the country and of the community as a whole. The country needs women, and particularly the more educated, intelligent and capable women, to fulfil their roles not only at home as mothers, but also in the economy as responsible and productive workers. We can no longer afford the luxury of expecting a woman to choose between fulfilment of her 'woman's role' in marriage and motherhood, and the personal satisfaction and growth of career achievement if she feels the need to express herself in a career. (No man is ever expected to make such an absolute choice between the satisfaction and joy of family life, and the opportunity to work and prove himself in the outside world.)

Table 2 Employment of men and women in managerial category

\begin{tabular}{lrrrrrrrrr}
\hline & \multicolumn{2}{c}{ Whites } & \multicolumn{2}{c}{ Coloureds } & \multicolumn{2}{c}{ Asians } & \multicolumn{2}{c}{ Blacks* } \\
Year & Male & Female & Male & Female & Male & Female & Male & Female \\
\hline 1969 & 72891 & 5277 & 236 & 43 & 1338 & 36 & 567 & 20 \\
1975 & 114461 & 10389 & 754 & $308^{+}$ & $3085^{+}$ & 67 & 3731 & 75 \\
1977 & 122853 & 15535 & 1017 & $80^{+}$ & $2901+$ & 125 & $690^{*}$ & $29^{*}$ \\
1979 & 139994 & 21606 & 1619 & 624 & 3208 & 206 & 2200 & 444
\end{tabular}

*The statistics for black managers are given for the sake of completeness, although they are not meaningful because as from the 1977 survey, statistics for Transkei and SWA/Namibia were excluded from the survey, and in the 1979 survey, the independence of Bophuthatswana and Lebowa also caused a large number of black managers and entrepreneurs to be excluded from these statistics. This may also explain other irregularities in numbers: ${ }^{+}$Elimination of SWA and Transkei statistics. Source: Manpower surveys of the SA Department of Manpower Utilization. 
Since the country needs both the genetic contribution of the above-average woman to the continuation of the population, and her intellectual and productive contribution to the economy, both government and community should assist working women in handling their dual roles. This could include providing or subsidizing day-care facilities for children, making day-care expenses taxdeductible, particularly in the case of mothers who are bread-winners, and providing and promoting careeroriented training for women wishing to make, or return to, a career.

In view of the real need for the educated woman in the labour market, the entire tax position of the working woman needs a re-evaluation in terms of present conditions rather than past traditions. Joint taxation of married couples proves to be a serious demotivator, particularly in the case of the educated and professional women whose husbands usually fall in the higher income brackets. And these are precisely the people that the economy needs most. ${ }^{7}$, np. 92 98, 129-127

\section{The employer - needs, practices and policies}

A growing number of South African employers fully realize that women could be at least a partial answer to their 'manpower' problem. Often their cry is: 'But where do we find suitable women?' The answer to this is not so easy because, due to policies and practices of the past, the lack of opportunities for training and experience, and lack of encouragement and of career guidance, such women are scarce. They still need to be identified, motivated, and developed. However, even in companies which are positive about women, discrimination usually still exists in a variety of forms.

It is important to understand that this discrimination is usually not deliberate or part of formal policy; it is so much part of a way of life that the people who perpetrate it seldom realize that they are being paternalistic or prejudiced. Examples relate to:

\section{Transferring a woman}

Personnel managers often decide that a woman is not transferable (and thus often also not promotable), without even discussing the matter with the individual concerned. They could not possibly know the domestic circumstances of each case, and thus discriminate by not considering or consulting her.

\section{Deciding about sending a woman out of town on an assignment}

Managers often do not consider women for a position or even an assignment that involves travelling, on the assumption that 'A woman cannot travel alone', 'Her husband will object', or 'Who'll look after her children?' Again, in an individual woman's position these objections may not pose a problem, and she often does not even have the opportunity to state her side of the case.

\section{Personal beliefs concerning working mothers}

Many managers believe personally that a woman should not work before her children reach a certain age; they do not want their wives to work; they are sure their wives could not cope well with the dual load of working and mothering - and they assume that this applies to all women, regardless of individual differences and circumstances, e.g. divorce, a supportive husband, a grandmother living in with the family, or the fact that some women are extremely capable and energetic. This bias is often subconscious, and they merely do not appoint women to challenging jobs - without voicing or testing their personal prejudices. 7 in $189-190$

\section{Making assumptions about a woman's desire for training, promotion, a real career}

Managers often generalize about women, assuming that all women have the same attitudes and objectives regarding work. They don't distiguish between the, admittedly large, group that merely want a job, and the growing proportion of women that are committed and careeroriented.

\section{'Traditional' differences in salary}

Women are often paid less than men doing the same work, sometimes due to open salary discrimination, sometimes by giving men and women different titles or scales when doing the same job, for example - personal assistant versus private secretary; assistant marketing manager versus marketing assistant; senior lecturer versus lecturer. Few employers realize how hurtful and demotivating this form of discrimination can be, how they often themselves contribute to the "lack of commitment' of which they accuse their female staff. And almost every woman earning a salary which in any way approaches being equal to that of an equivalent male, has probably heard with surprise and almost indignation: 'You earn a jolly good salary for a woman!'

The fact that many of these instances of discrimination are subtle and even well intended 'gentlemanly protection' often makes it even more difficult to dismantle these habits and practices than it would have been if they were open and conscious.

\section{Overcoming unconscious discrimination}

In order to overcome traditions of discrimination, and at the same time better utilize their women employees, employers may indeed have to become more discriminating (in contrast to discriminatory) in their personnel practices and policies.

Firstly, the general assumption is that a man wants, and must indeed have a career, and that it is worthwhile to invest in his training and development until he proves the opposite. At the same time it is usually assumed that a woman is only a short-term employee; is not a career proposition worthy of investment, until she proves herself more than worthy of a career! The case study 'Perfectly Pure Peabody's'8 shows how this problem exists not only in South Africa but also in the United States in spite of all its 'Equal Opportunities' efforts. Many companies could benefit if they would establish a firm pattern of being discriminating about people, rather than discriminatory; if they would firstly identify and consider important achievement-related qualities such as intelligence, sense of responsibility, commitment, creativity, initiative, energy and enthusiasm, (which could be found and developed in women as well as in men) when planning for an individual's career, rather than using the person's sex as a first point of reference. The frequently made 
generalization that a woman's 'inevitable' sex-related role precludes her from career-worthiness too easily becomes a self-fulfilling prophecy.

Secondly, employers easily make the mistake of believing that their subordinates, and particularly 'minority groups' such as women, are motivated mainly by what Herzberg' called 'hygiene factors' such as salary, rather than by the real motivators providing job satisfaction, such as challenge and opportunity for growth and achievement. Too often one hears phrases like 'She is only working as a passtime or for pocket money' or 'She holds a good job for a woman'. More and more women do want meaningful positions in which they can grow with their careers.

Thirdly, there is a very common belief that women are poor career propositions on account of their 'high absenteeism and job turnover rates.' But unbiased statistics in many cases refute this myth, 7 . pn $54-57,10,11.12$ even on relatively low job levels. What usually happens is that statistics for all women are compared with those for all men, and the fact that women generally occupy lowerpaid, or more menial jobs than men, is disregarded. The real reason for the low job stability usually lies rather in the nature and level of their jobs, than in the fact that they are women. This often biased generalization, with consequent lack of career development of women, again becomes a self-fulfilling prophecy. ${ }^{13}$

Various approaches are available to employers wishing to reduce the possible erosion of their female (and also male) staff due to resignation: realistic job previews before appointment, in which both employer and employee reduce the 'reality shock' of the new job by open two-way discussion about expectations and reality; individual career planning and guidance; use of a mentor to help the woman in her development; ${ }^{14}$ early job challenge and opportunity for success. ${ }^{15, p 3}$ Employers tend to feel helpless to prevent a woman's resignation and easily ascribe it to the 'inevitable' reasons of marriage, pregnancy or a husband's transfer. Research in the United States ${ }^{16}$ has proved that this is exaggerated, showing that women leave as often for reasons which the company could have prevented, such as frustration, and lack of challenge, of opportunity and of a meaningful job, lack of promotional prospects, financial reasons, much the same reasons for which men usually leave. The reasons for which men leave are regarded as 'normal', those for which a woman leave are held against her. Employers also seldom realize that the way they treat women, conditions of employment and career prospects often determine whether a woman will 'opt out and stay at home' after a baby, or will return to her career as soon as possible. Employers like the Defence Force, who have positive policies in this regard, have reaped the benefits of a stable and valuable female labour force.

Employers may well say: 'But women do get opportunities if they want them. We have two, oh yes, three women in management positions.' But these positions are seldom above middle management, and are usually in staff rather than line positions. Of course this is partly because many women lack career-oriented and technical training, or because they have had interrupted careers. But many men without appropriate formal training, who may have done a good deal of job-hopping when they were young, do achieve senior line positions. The Peabody's Case study, ${ }^{8, p}{ }^{109}$ where two of Sarah Barrington's male subordinates were promoted to 'experience-giving' positions right past her, while she was not promoted due to 'lack of experience', serves as one of many examples of this kind of situation. Many women may well be quite happy (maybe they and some of their colleagues would even say 'lucky') with the positions they have reached. But before a woman reaches a management position, she has usually more than earned it, and proved herself far beyond any doubt and tradition.

My concern is that not only women, but also many employers and the country's economy, lose out in this way. When considering the few women in South Africa who have reached senior management positions, I have little doubt that with their abilities and commitment, had they been men, they would have been in really top positions. Similarly I believe that many women who are stuck in administrative or secretarial positions could have handled middle management positions well, had they been given more opportunities and encouragement, had their employers regarded them as career propositions. In a country so desperately short of capable people, the employers doubtlessly lose out if they lack imagination regarding the utilization of women, if they use people two or three levels lower than their real capacity. ${ }^{17}$ I believe that due to tradition, the 'Peter Principle' applies to far fewer women in South Africa, than men. A woman is seldom promoted to 'her level of incompetence' - she often sits waiting, well below her level of competence frustrated, hesitant to push herself, but eager to take on new responsibilities and more meaningful tasks.

\section{An imaginative approach}

Companies do need to have an imaginative and creative approach if they want to get the best from, and give the best to, their womenfolk. I am not in favour of reverse discrimination as one sometimes finds in the United States, ${ }^{7}$ pp $159-162$ but I believe that, in the interim at least, achieving women deserve special attention to halp them to overcome the negative attitudes and traditions that culture has instilled both in them, and their environment. These problems will be discussed briefly later in this article. According to Hall and Hall ${ }^{15}{ }^{7}$ (a husband-and-wife team who have done extensive work in the organizational behaviour area) 'there is a need for more than equal opportunity for women. Given the internal barriers such as low self-esteem and role conflict . . . it may also be important for organizations to provide support to help overcome these barriers.'

No company could be expected to make costly special allowances to cater for the non-careerrelated responsibilities of women. If a woman does actually get equal treatment in all ways, she will find it difficult to justify on economic grounds a claim for costly creches, or a request for time off for shopping or to go to the hairdressers; (although men do get time off to take the car to the garage or for a round of 'business golf!') Most responsible people - men or women - who take time off for private reasons in any event more than make it up to their employers in some way.

On the important issue of home responsibilities, I believe that the woman's much-needed support in this 
area should in the first place come from her husband and family, who could do a lot by helping to share the load; and from society and the government who have a vested interest in the health, continuation, and quality of the future generation, of which children of working mothers comprise a rapidly increasing proportion.

The employers of women do, however, also have an interest in the arrangements for daycare, since their women employees are likely to be more relaxed and more productive if they know that their children are in good hands.? $p p 200-202$ So, although I would never expect firms to take over this responsibility, the firms that take the initiative to help with this problem facing many working women, are usually well rewarded by the commitment of the women who appreciate their firm's caring for them as a whole person, and not only as the person doing a particular job. Such firms attract a good quality woman, since the woman who takes her home responsibilities seriously, (and would not work unless adequate childcare is available) usually has the same approach to her work. And they usually keep her, because they have a competitive advantage in the labour market above the employer who is not willing to help in this area. This does not mean that firms have to have a creche on the premises. (They are after all in business, not in social services.) But they might help in other ways, by subsidizing creche costs in the suburb where the woman lives, by creating morning jobs (from which employers usually get better value for money per hour in any event), by instituting flexitime (which might be good for workers of both sexes), or by allowing a responsible woman to take work home when her child is ill.

Similarly firms that have a progressive policy regarding maternity leave often also benefit as much as the women concerned. They attract a more career-oriented woman, and are likely to enjoy her services between babies, and for about 30 years after she has completed the full-time part of her family responsibilities. In this way they need not lose what they have invested in her training, even in the early years. The Defence Force case is an example of this approach, but several South African banks, building societies and retailers have also implemented this policy with good results.

Furthermore, beyond the practical considerations, if a man must have time off to meet his military commitments, is it not equally important for the country that a woman have time off for family formation, without prejudice to her career development and opportunity for intellectual achievement?

\section{Effects of the social environment on the working woman}

The culture and social environment in which men and women grow up is probably the determining factor affecting attitudes regarding women at home and at work. I believe that this deserves the serious attention of all men and women concerned, since much misunderstanding exists regarding the changing roles of men and women. Whereas the feminist movement has made a valuable contribution in pointing out important issues and making both men and women aware of some injustices, the extremely militant groups have certainly done considerable harm by polarizing men and women. This situation has been aggravated by the media's eagerness to latch onto any dramatic, although possibly not representative, story. In many cases women feel cheated and bitter, are over-conscious of their frustrations and blame everything on 'male chauvinist pigs' and discrimination, rather than taking a rational look at the problem; while men feel threatened and under pressure, and believe that they are being unjustly accused since they really meant to be protective and 'gentlemanly', and had only treated women as tradition and habit required. Men are, understandably, often stunned by the sudden change, and the violence of it - because some women have become aggressive instead of assertive, almost overnight.

The real cause of the problem is neither conscious, arrogant, deliberate male chauvinism, nor an inherent lack of careerworthiness in women, but simply the role expectations and stereotyped views that stem from our culture. And I would appeal to the press to concentrate on the positive elements and many newsworthy developments in the changing situation, rather than both perpetuating sexbased stereotypes, and overplaying the conflict between men and women, as they are generally in the habit of doing.

An interesting example of the effect of culture on working women is the way in which certain jobs are regarded as 'men's jobs', way beyond the reach of a woman, however capable or intelligent she may be. I recently even heard a specific post as a dietician described as 'definitely a man's job!'

Two Americans, Ferber and Lowry, ${ }^{18}$ conducted interesting research in which they compared the acceptance of women in different professions and occupations in different countries - and found dramatic differences between countries, clearly showing that culture, and not innate ability, influences the distribution of 'women's work.'

It is essential that men and women get together, and realize that they are not really the adversaries that the feminists and the media often make them out to be; that both at home and at work they have mutual interests and a shared future, and that the future can be enriched for all concerned (including their employers and the entire community) if men and women were to stimulate and encourage one another to each contribute in his or her own way, and all develop to their full potential.

\section{Problems typically experienced by working women}

Much has been said, written and researched about problems facing working women. Reference was made to some of them in the previous parts of this discussion, and the article 'More than a woman-sized problem'19 deals with this topic at some length. Some of the major problems affecting women in the work situation will only be briefly mentioned here.

Of course all people experience some problems at work - that is just life! But for most working women, to paraphrase Shakespeare, problems 'come not in single spies, but in batallions', closely-linked batallions at that.

Without becoming problem-oriented or negative, it is essential that employers, women and male colleagues get to understand the nature of these problems, if women are to develop to their full potential. 
The problems fall into two main groups: Those within the women themselves, and those that exist in the women's environment. Both these groups of problems result from the culture in which men and women were brought up, from role expectations and attitudes conditioned into men and women.

\section{Problems within women}

- Women tend to lack confidence in themselves and their abilities. The French author Victor Hugo illustrated his thorough understanding of women when he said: 'A man has as exaggerated an idea of his rights as a woman has of her wrongs.'

- If things go wrong, women often indulge in excessive self-reproach; if things go right, they tend to be overmodest - as any 'lady' should be!

- Related to women's lack of self-confidence and cultural conditioning is their lack of assertiveness, ${ }^{20}$ which causes them to be submissive and accept negative situations, and then sometimes flare up and become overly aggressive when they have had 'too much'. They must learn that they can hold their own rightfully and regulary without being aggressive or infringing on the rights of others.

- The achieving woman is often an individualist who tends to get things done on her own, rather than in a team - she must be an individualist to have the courage to get out and 'do her own thing.' But she must also learn to work in a team and draw on the mutual support of other men and women if she really wants to get ahead. It is also essential that she gets to understand and cope with office and career politics. She need not initiate political activity - but she will lose out if she is too forthright or naive about this important element of modern business life.

- Another very real problem is the feeling of guilt and the overload of responsibilities with which the working mother has to cope every day. If she does not learn to cope with these, not only she, but also her work and her family can be affected.

\section{Problems in the environment}

The problems in the environment are reasonably wellknown, and have been discussed earlier. They are:

- Tradition

- Discrimination

- The fact that women are often still seen in terms of stereotypes and sex-related roles

- Lack of recognition and of encouragement of the contributions and of the potential of many careerminded women, both by employers and relatives, such as husbands and parents

- The almost inhuman load that the dual roles at work and home can place on a woman if she does not get some form of support.

\section{Overcoming these problems}

There are three important things for a woman to remember when dealing with the problems mentioned and with the many others not mentioned:
- She must try to understand the nature and causes of the problems facing her - that they are mostly caused by culture; that even if people should discriminate against her or be paternalistic towards her, this is usually not intentional, and may even be well intended; it is also not aimed against her as an individual, but just a matter of habit or tradition that people have not carefully considered, that they do not realize can be hurtful. This understanding will help her to handle the problems rationally and more effectively. It does not mean she must accept and live with the problems - but she will be less subjective and emotional, and more constructive about challenging them if she bases her approach on an understanding of 'both sides of the story'.

- She must realize that until she has overcome, or at least reduced, the first group of problems (the selfdefeating attitudes with which most women are brought up) she cannot expect to overcome the problems and prejudices in her environment.

- Careful budgeting of both time and energy is even more crucial to the career woman than to the 'career man', particularly if she has home responsibilities too. She must learn to set priorities, not be too proud to ask for support when needed, so that she has time and reserves to enjoy being a woman and a human being. Because if she does not grant herself the 'luxury' of relaxation and of simple joys, career success may demand too high a price, and the lack of 'input' into her life will in due course also start to affect her ability to produce 'output', both in her work and her private life.

By understanding the abovementioned aspects of the situation of the working woman:

- the need for her services in the South African economy

- the mutual dependence between employer and working woman

- the influence of culture and social environment on the working woman and

- the problems facing the working woman,

both employers and women would be better able to fully benefit from the wealth of potential which has so far been wastefully under-estimated and under-utilized in South Africa.

In conclusion a quote from Olive Schreiner. ${ }^{21}$ What she said in the early 1900's, still holds true today: 'Is it to be, that, in the future, machinery and the captive motorforces of nature are largely to take the place of human hand and foot in the labour of clothing and feeding the nations; are these branches of industry to be no longer domestic labours? - Then, we demand that in the factory, the warehouse, and the field, wherever machinery has usurped our ancient labour-ground, we also should have our place, as guiders, controllers, and possessors. Is child-bearing to become the labour of but a portion of our sex? - Then we demand for those among us who are allowed to take no share in it, compensatory and equally honourable and important fields of social toil. Is the demand for child-bearing to become so diminished that, even in the lives of those among us who are child-bearers, 
it shall fill no more than half a dozen years out of the three-score-and-ten of human life? - Then we demand that an additional outlet be ours which shall fill up with dignity and value the tale of the years not so employed. ... Slowly but determinately, as the old fields of labour close up and are submerged behind us, we demand entrance into the new. We make this demand, not for our own sake alone, but for the succour of the race ... In the confusion and darkness of the present, it may well seem to some that woman, in her desire to seek for new paths of labour and employment, is guided only by an irresponsible impulse; or that she seeks selfishly only her own good, at the cost of that of the race, which she has so long and faithfully borne onward. But, when a clearer future shall have arisen and the obscuring mists of the present have been dissipated, may it not then be clearly manifest that not for herself alone, but for her entire race, has woman sought her new paths?'

\section{References}

1. INTERNATIONAL LABOUR OFFICE: Womanpower. Geneva, 1975 pp 7-9, 12, 15, 35.

2. VAN DER MERWE, SANDRA: A Portrait of the South African Woman Manager, S. Afr. J. Bus. Mgmı. 1979, pp 58-59.

3. VERMAAK, J.A. (1975): Die vraag na en aanbod van mannekrag in die R.S.A., Deel II. Pretoria, Human Sciences Research Council, 1975, MM-56 pp 4, 28, 79-81, 90-91.

4. VERMAAK, J.A. (1978): Vraag na en aanbod van mannekrag in die R.S.A. in die jaar 1981, Deel I. Pretoria, Human Sciences Research Council, MM-70, 1978.

5. SMIT, TRUIDA: The other half: Towards better utilization of women's potential in South Africa. Bus. Mgmt. 9, pp 36-42.
6. S.A. DEPARTMENT OF LABOUR: Manpower Survey No 12. Pretoria, April 29, 1977, pp 3, 32.

7. SMIT, TRUIDA: Development of the managerial potential of South African women, Unpublished MBL dissertation, UNISA, Pretoria, 1978.

8. GORDON, F.E. \& STROBER M.H.: Bringing women into management. McGraw-Hill, New York 1975, pp 79-111.

9. HERZBERG, F: One more time: How do you motivate employees? Harv. Bus. Rev. Jan - Feb 1968; pp 53-62.

10. GAUDREAU, P.A.: Investigation of sex differences across job levels. Ph.D. dissertation, Rice University, 1975; pp 2, 72 - 74, 79.

11. WESSELS, D.M. (1975): Manpower requirements and the utilization of women: The views of fifty employers in nine major industry groups. Pretoria, Human Sciences Research Council, 1975, MM-52; pp 55, 63, 77-78.

12. WESSELS, D.M. (1977): Vroue in bedryfswerk. Pretoria, Human Sciences Research Council, 1977, MM-66; pp 84-86.

13. TORREY, J.W. (1973): A psychologist's look at women. J. Cont. Bus., Summer 1973; p 27.

14. HENNIG, M. \& JARDIM, A.: The managerial woman. New York Anchor Press/Doubleday, 1977; pp 129-135.

15. HALL, D.T. \& HALL, F.S.: Career Development: How organizations put their fingerprints on people. In: (ed) Dyer, L.: Careers in organizations, 1976. Cornell Univ. New York.

16. BOYLE, B.M.: Equal opportunity for women in smart business. Harv. Bus. Rev. May - June 1971; p 90.

17. SAMUELSON, PAUL A: Economics, 10th Ed McGraw-Hill, New York, pp $781-794$.

18. FERBER, M.A. \& LOWRY, H.M.: Woman's place: National differences in the occupational mosaic. J. Mark., July 1977; pp $22-30$.

19. SMIT, TRUIDA: More than a Woman-sized problem, People \& Profits May 1978, pp 21-25, 35.

20. BLOOM, L.Z. et al: The new assertive woman. New York, Delacorte Press, 1975.

21. SCHREINER, OLIVE: Woman and labor, In: (ed) Reeves, NI. Chicago, Aldine Publishing, 1971; pp 170-171. 